\title{
Concentrations and Geographical Variations of Selected Toxic Elements in Meat from Semi-Domesticated Reindeer (Rangifer tarandus tarandus L.) in Mid- and Northern Norway: Evaluation of Risk Assessment
}

\author{
Ammar Ali Hassan ${ }^{1, *}$, Magritt Brustad ${ }^{1}$ and Torkjel M. Sandanger ${ }^{1,2}$
}

1 Centre for Sami Health Research, Department of Community Medicine, Faculty of Health Sciences, University of Tromsø, N-9037 Tromsø, Norway; E-Mails: magritt.brustad@uit.no (M.B.); torkjel.sandanger@uit.no (T.M.S.)

2 Norwegian Institute for Air Research (NILU), Fram Centre, N-9296 Tromsø, Norway; E-Mail: tsa@nilu.no

* Author to whom correspondence should be addressed; E-Mail: ammar.ali.hassan@uit.no; Tel.: +47-776-46-934; Fax: +47-776-44-831.

Received: 13 March 2012; in revised form: 16 April 2012 / Accepted: 23 April 2012 /

Published: 4 May 2012

\begin{abstract}
Meat samples $(\mathrm{n}=100)$ from semi-domesticated reindeer (Rangifer tarandus tarandus L.) were randomly collected from 10 grazing districts distributed over four Norwegian counties in 2008 and 2009. The main aim was to study concentrations and geographical variations in selected toxic elements; cadmium $(\mathrm{Cd})$, lead $(\mathrm{Pb})$, arsenic $(\mathrm{As})$, copper $(\mathrm{Cu})$, nickel $(\mathrm{Ni})$ and vanadium $(\mathrm{V})$ in order to assess the risk associated with reindeer meat consumption. Sample solutions were analysed using an inductively coupled plasma high resolution mass spectrometer (ICP-HRMS), whereas analysis of variance (ANOVA) was used for statistical analyses. Geographical variations in element concentrations were revealed, with $\mathrm{As}$ and $\mathrm{Cd}$ demonstrating the largest geographical differences. No clear geographical gradient was observed except for the east-west downward gradient for As. The As concentrations were highest in the vicinity of the Russian border, and only Cd was shown to increase with age $(p<0.05)$. Sex had no significant effect on the concentration of the studied elements. The concentrations of all the studied elements in reindeer meat were generally low and considerably below the maximum levels (ML) available for toxic elements set by the European Commission (EC).
\end{abstract}


Thus, reindeer meat is not likely to be a significant contributor to the human body burden of toxic elements.

Keywords: reindeer meat; toxic elements; Norway; Arctic food; risk assessment

\section{Introduction}

In recent years, there has been considerable concern over the extent of toxic elements in the environment and their possible negative health effects. The limited amounts of data on local sources, as well as the increased number of slaughtered reindeer, necessitate a need for the continuous monitoring of such elements in meat to secure food safety for the consumer [1-6]. The concentration of toxic elements in animal tissues depends on the animal's species, dietary concentration of the element, tissue absorption, concentrations of other elements in the animal tissue and the body's homeostatic control mechanism for the element [7]. These elements are toxic for both human and animals, and cause a range of diseases [8-12]. Furthermore, the highest concentrations have been found in tissues such as kidneys, liver and bones [1,3,13,14]. Geographical variations in the concentrations of toxic elements in meat, liver and kidneys from reindeer have previously been demonstrated [15-17].

Both natural and anthropogenic components contribute to geographical variations in the concentration of toxic elements. Moreover, the difference in exposure patterns may be due to different type of diets, as both animal diet preferences and the type of vegetation, vary from one place to another. Differences in exposure are therefore expected in areas with a different animal density and a different availability of lichens. Toxic metal concentrations in animals have been reported to be associated with the distance to pollution sources, thus districts located close to the sources have higher concentrations than other areas [18,19]. Wind frequency and direction also influence the atmospheric deposition of toxic metals [20].

The main reindeer summer/autumn feed are grasses, sedges, twigs, leaves and mushrooms [21]. Some plants (metallophytes) have the ability to absorb and accumulate more toxic elements from the soil in their tissues, even when soil concentrations are low, compared with other ones within the same geographical area. Additionally, the elements composition of plants vary within species as well as at the various stages of plant growth [22]. The decreased $\mathrm{pH}$ (increased acidity) of the soil as a result of acid rain affects the solubility and mobility of some toxic elements (e.g., an increase in the case of Cd) $[23,24]$. In this way, their uptake by plants and accumulation by animals may increase. However, areas in the southernmost part of Norway are the ones most affected by acid rain due to the long-range atmospheric transportation from Central and Western Europe compared to areas in the north of Norway $[25,26]$. As a consequence of this, Norwegian cervine animals - particularly reindeer-from southern Norway have previously exhibited elevated liver and kidney cadmium levels [1].

Lichens are the main reindeer winter feed, with a varied distribution among the different grazing districts, and have the ability to accumulate toxic elements from the atmosphere [27-29]. In former studies, lichens also revealed the greatest variation in metal concentrations compared with other plants collected from contaminated and reference areas in Swedish Lapland [19]. 
Areas close to the Norwegian-Russian border are the primary issue of concern due to the location of the two Russian towns of Nikel (nickel smeltery) and Zapoljarny (briquette industry). The town of Nikel is located $7 \mathrm{~km}$ from the Norwegian border, while the town of Zapoljarny is located $30 \mathrm{~km}$ further east. The high atmospheric level of $\mathrm{Ni}, \mathrm{Cu}, \mathrm{Co}$ and $\mathrm{As}$ previously measured from the Norwegian area of Svanvik close to the Russian border was reported to be due to the release from the smelting activities in Nikel and Zapoljarny [20,30]. In addition to the known Russian sources, the presence of local mining facilities and military activities in some districts acts as potential point sources, and has been an issue of concern.

The main purpose of this project was to study the concentrations and geographical variations of selected toxic elements in meat from semi-domesticated reindeer in the selected grazing districts in mid- and northern Norway in order to assess the risk associated with reindeer meat consumption.

\section{Materials and Methods}

\subsection{Sample Collection and Preparation}

Meat samples $(n=100)$ from the neck-region were randomly collected from semi-domesticated reindeer in 10 different grazing districts located in northern and middle Norway in the period from October-December 2008 and September-December 2009. The samples were collected from four different counties distributed as follows: Finnmark County (seven districts), Troms County (one district), Nordland County (one district) and South-Trøndelag County (one district). The selection of the 10 districts was based on obtaining a broad geographical range and the susceptibility of certain districts to pollution from mines, smeltery and military activities (Figure 1). The selection of seven districts from Finnmark County which is the biggest and northernmost Norwegian county was based on the fact that this county has the largest number of semi-domesticated reindeer and $50 \%$ of the total number of reindeer grazing districts in Norway. The districts of Eastern Sør-Varanger, Pasvik/ Sør-Varanger and Varanger Peninsula are located near the Norwegian-Russian border, where the contamination from mines and smeltery activities is taking place. Spierttagáisá is located in a military activity area, whereas Karasjok West is a neighbouring district. There is also mining work taking place in Ábborašša, which is close to Fávrrosorda a neighbouring district.

Our focus was on young animals (1.5 years old), which represented $77 \%$ of the total samples. However, calves (approximately10 months old) and older animals ( $>2$ years old) with the respective proportions of $12 \%$ and $11 \%$ had to be selected due to the limited availability of 1.5 year olds in some districts $(n=4)$. There were 52 males and 48 females of the 100 selected reindeer.

All samples were collected directly after the slaughter/dressing process and carcass weighing in acid-rinsed glasses. The glasses were labelled with sample type, carcass number, district name/number and date of sample collection. The samples were kept cool in a cooling box (at approximately $4{ }^{\circ} \mathrm{C}$ ) and then moved the same day to a $-20{ }^{\circ} \mathrm{C}$ freezer until they were shipped frozen to the laboratory for analysis. All of the animals from the collected samples were healthy, i.e., had passed the veterinary meat inspection. 
Figure 1. Map of the study area.

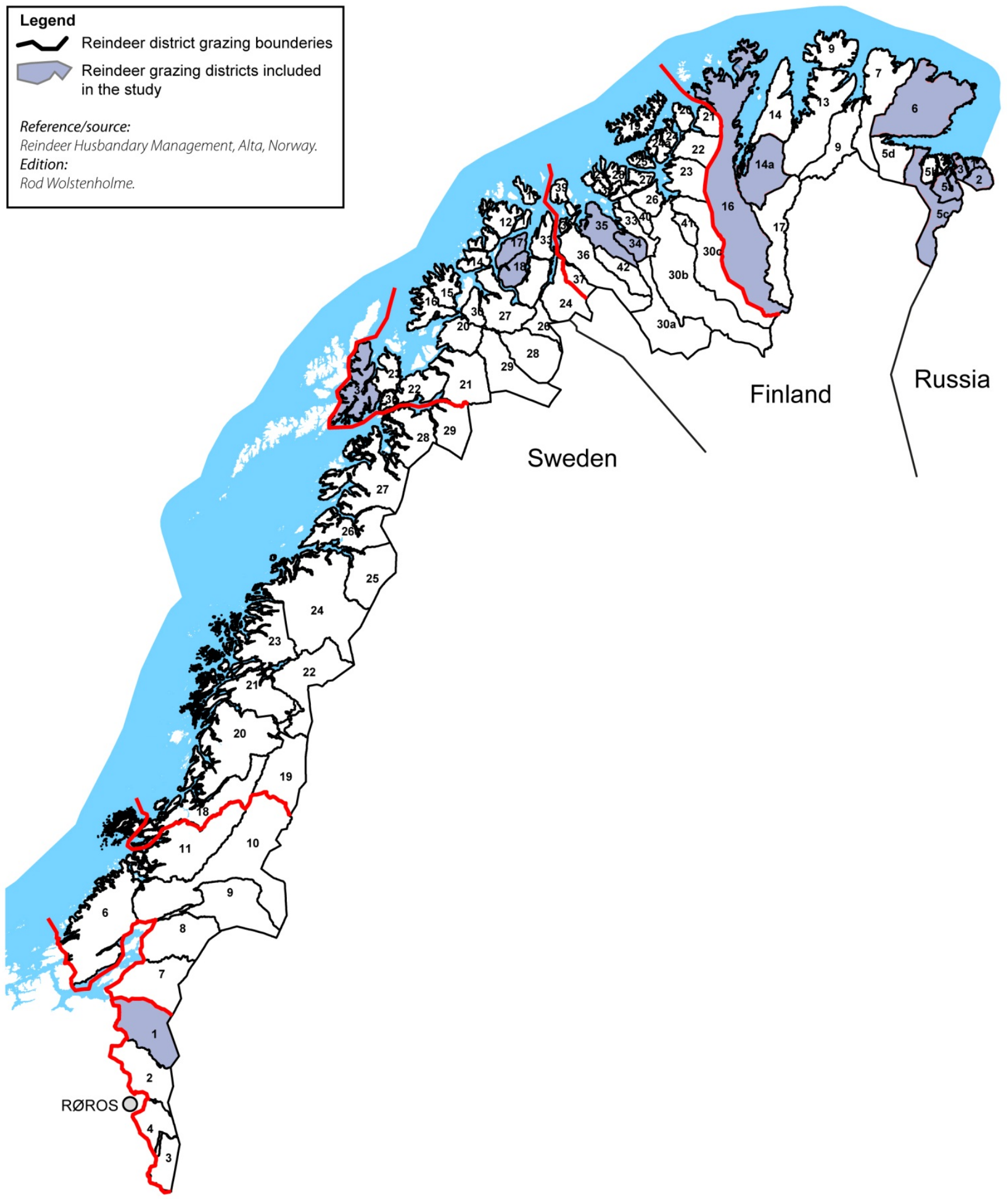

\subsection{Chemical Analysis}

The samples were separately decomposed using a microwave oven technique, with concentrated supra-pure $\mathrm{HNO}_{3}(5 \mathrm{~mL})$ and $\mathrm{H}_{2} \mathrm{O}_{2}(3 \mathrm{~mL})$ being added to the decomposed sample $(0.6-0.7 \mathrm{~g})$ before undergoing microwave oven treatment. The following temperature regimes were subsequently used in 
the microwave oven: $20-50{ }^{\circ} \mathrm{C}(5 \mathrm{~min}), 50-100{ }^{\circ} \mathrm{C}(10 \mathrm{~min}), 100-180{ }^{\circ} \mathrm{C}(5 \mathrm{~min})$ and $180{ }^{\circ} \mathrm{C}(15 \mathrm{~min})$. After cooling the heated decomposed sample, the solution was diluted to $50 \mathrm{ml}$. The sample solution was then analysed using an inductively coupled plasma high resolution mass spectrometer (ICP-HRMS), Bremen, Germany. All standards and calibration solutions contained 1 ppb Rhenium (Re) as the internal standard, together with $1 \%$ nitric acid $\left(\mathrm{HNO}_{3}\right)$. The calibration curve was verified by standard quality control (QC) sample, National Institute of Standards and Technology (NIST, USA). The resolutions used for the elements were low (at 10) for $\mathrm{Cd}$ and $\mathrm{Pb}$, middle (at 20) for $\mathrm{Cu}, \mathrm{V}$ and $\mathrm{Ni}$, and high (at 30) for As. The lens adjustment was optimized daily for maximum intensity and top separation. The analyses were done by the NILU (Norwegian Institute for Air Research) Laboratory (Kjeller, Norway). The laboratory is accredited for the methods used in the analyses according to NS-EN ISO/IEC 17025, No. TEST008. The limits of detections (LODs) for the studied toxic elements were three times standard deviation (SD) of the laboratory blanks, whereas the limits of quantifications (LOQs) were 10 times the SD of the blanks, decomposed simultaneously with the meat samples.

\subsection{Statistical Analysis}

STATA/SE 11.0 for Windows (STATA Corp. College Station, TX, USA) was used for the statistical analyses. Laboratory results for elements below the limit of detection (LOD) were given a numeric value at half the $\operatorname{LOD}(\mathrm{LOD} / 2)$ according to accepted statistical practice [31]. All toxic element concentrations, except for $\mathrm{Cu}$ which was normally distributed, were positively skewed (skewed to the right). Therefore, all concentrations were log transformed to obtain a normal distribution before statistical evaluation. A standardized residuals test was conducted prior to the log transformation in order to check for possible outliers (observations that were more than three standard deviations from the mean). Consequently, all outliers were removed $(\mathrm{n}=10$, details in results and discussion).

An analysis of variance and covariance (ANOVA), with the specific element as a dependent (outcome) variable and the district, age and sex as independent (explanatory) variables, was used to test for the effect of the independent variables on toxic element concentrations. Bonferroni multiple comparison tests were used to test for significant differences in toxic element concentrations among the 10 grazing districts, using the specific element as an outcome and the districts as a factor variable. A Welch test was used whenever the homogeneity of variance was violated. The level of statistical significance was set at $p<0.05$ for all the statistical analyses.

\section{Results and Discussion}

The present study is unique since it is the first of its kind to include such a large number of animals to study the concentrations and geographical variability of toxic elements in meat from semi-domesticated reindeer. Moreover, the assessment was done using meat that is more relevant for human consumption. Further, the reindeer originated from 10 different grazing districts covering a large geographical area extending from the middle to the northernmost part of Norway.

The overall concentrations of toxic elements in meat samples from all animals $(n=100)$ are presented in Table 1. The results were presented as percentage (\%) of samples above LOD, geometric mean $(\mathrm{GM})$, arithmetic mean \pm standard deviation $(\mathrm{AM} \pm \mathrm{SD})$, range (Min-Max) and coefficient of variation $(\mathrm{CV} \%)$. Geographical variations in toxic element concentrations between some districts were 
demonstrated (Table 2). Detailed result of the multiple comparison tests for concentrations among the 10 grazing districts are presented as supplementary material (Table 1S). Sex had not any significant influence on toxic element concentrations.

Table 1. The overall toxic element concentrations (ng/g ww) in reindeer meat.

\begin{tabular}{ccccccc}
\hline Element & n & \% detected & GM & AM \pm SD & Min. & Max. \\
\hline $\mathrm{Cd}$ & 98 & 99 & 1.7 & $2.5 \pm 2.5$ & $<0.37$ & 11 \\
$\mathrm{~Pb}$ & 98 & 92 & 1.5 & $2.7 \pm 3.1$ & $<0.19$ & 20 \\
$\mathrm{As}$ & 99 & 100 & 8.1 & $20 \pm 32.1$ & 0.7 & 135 \\
$\mathrm{Cu}$ & 98 & 100 & 1,439 & $1,469 \pm 296$ & 830 & 2,357 \\
\hline
\end{tabular}

Legend: $n=$ Number of observations. \% detected= Percentage of samples within the limit of detection (LOD); $\mathrm{GM}=$ Geometric mean. $\mathrm{AM} \pm \mathrm{SD}=$ Arithmetic mean \pm standard deviation. Min-Max= Minimum-Maximum; $\mathrm{CV}=$ Coefficient of variation. Note: The limits of detection (LODs) for the toxic elements (e.g., 0.37 and 0.19) were stipulated by calculating the mean value of all LODs for the specific element. Numbers of samples were less than 100 due to removal of outliers.

Toxic element concentrations in 10 samples were outliers and have been removed from the statistical analyses. The detected outliers were: One animal (1.5 years) from Eastern Sør-Varanger with an As concentration of $161 \mathrm{ng} / \mathrm{g}$ ww; two animals from Kanstadfjord; a 1.5 years old and an older one ( $>2$ years) with Cd concentrations of 13 and $15 \mathrm{ng} / \mathrm{g}$ ww, respectively; two animals: a calf from Varanger Peninsula and an older one ( $>2$ years) from Spierttagáisá with $\mathrm{Pb}$ concentrations of 28 and $23 \mathrm{ng} / \mathrm{g}$ ww, respectively; two animals (1.5 years) from Fávrrosorda and Karasjok West with $\mathrm{Cu}$ concentrations of 161 and $2837 \mathrm{ng} / \mathrm{g}$ ww, respectively; one animal (1.5 years) from Tromsdalen with $\mathrm{Ni}$ concentration of $19 \mathrm{ng} / \mathrm{g}$ ww; two animals (1.5 years) from Spierttagáisá and Karasjok West with V concentrations of 5.1 and $8.3 \mathrm{ng} / \mathrm{g} \mathrm{ww}$, respectively.

\subsection{Cadmium (Cd)}

Cadmium was detected in $99 \%$ of the meat samples, and had the second largest geographical variation after arsenic. The geographical variations in cadmium concentrations are presented in Tables 2 and 3.

The presence of older animals in some districts revealed a significant district $\times$ age interaction, therefore stratified data were given for Cd concentrations in districts with mixed age groups (Table 3). Calves and young animals demonstrated no significant difference in $\mathrm{Cd}$ concentration across geography $(\mathrm{GM}=0.9$ and 1.5 , for calves and young animals respectively), while older animals ( $>2$ years old) showed a higher $\mathrm{Cd}$ concentration $(\mathrm{GM}=4.3, p<0.01)$. The increase in Cd concentration with age was in accordance with previous studies [15,16,32]. A Finnish study on toxic metals in reindeer from four districts in Lapland has shown comparable muscle Cd concentrations ranging from 1 to $6 \mathrm{ng} / \mathrm{g} \mathrm{ww} \mathrm{[15].}$ Moreover, Cd concentrations from the present study were up to 100 times lower than those found in reindeer muscle (mean $=580 \mathrm{ng} / \mathrm{g} \mathrm{ww}$ ) originating from Karelia in the Russian Federation [33].

$\mathrm{Cd}$ concentrations in some districts from the present study were higher than those from reindeer muscles collected from three Greenlandic districts, whereas concentrations from the districts of Essand/Røros, Ábborašša, Kanstadfjord and Fávrrosorda were comparable to that reported from one district $(\mathrm{GM}=3 \mathrm{ng} / \mathrm{g}$ ww) [17]. The high Cd concentration in Kanstadfjord was due to presence of some older animals $(n=4)$. Furthermore, high $\mathrm{Cd}$ concentration in Fávrrosorda might be due to 
atmospheric deposition from the neighbouring district Ábborašša with its gold mining activity. The high concentration in Essand was probably a result of acid rain due to atmospheric transport of industrial pollution from Europe which has previously been reported to affect southern Norway to a greater extent than northern part of the country [34-36].

\subsection{Lead $(P b)$}

$\mathrm{Pb}$ was detected in $92 \%$ of the meat samples. Concentrations of the $\mathrm{Pb}$ among the various grazing districts did not vary to the same degree as for As and Cd (Table 2).

The study on Finnish reindeer by Rintala and colleagues had also reported little differences in concentrations of $\mathrm{Pb}$ among different Lapland areas [15]. Even so, the $\mathrm{Pb}$ concentrations detected in this study were much lower (10 to 20 times) than those reported in reindeer meat by the same reference above. The $\mathrm{Pb}$ concentration from Fávrrosorda in the present study (GM=7.4, $\mathrm{AM}=8.6 \mathrm{ng} / \mathrm{g}$ ww) was an exception and could be compared to the concentration from the southern, western and eastern parts of Finnish Lapland, in which the $\mathrm{Pb}$ concentration was half of that detected from northern Lapland [15]. The mean $\mathrm{Pb}$ concentration of $2.14 \mu \mathrm{g} / \mathrm{g}$ ww previously measured from the Karelian reindeer muscle in Russia was 289 times higher than the greatest level of $\mathrm{GM}=7.4 \mathrm{ng} / \mathrm{g}$ ww measured in the present study [33].

The $\mathrm{Pb}$ concentration was five times higher $(p<0.01)$ in Fávrrosorda (a neighbouring district) compared to Ábborašša (gold mining facilities). This suggests that the deposition of lead occurs in the neighbourhood of the mining area rather than the mining area itself, which is based on the wind direction and is in accordance with results presented elsewhere [19]. The $\mathrm{Pb}$ concentration measured from Fávrrosorda in this study was in good agreement with those from unknown point sources in Greenlandic caribou and reindeer muscles from Isortoq $(\mathrm{GM}=7 \mathrm{ng} / \mathrm{g} \mathrm{ww})$ in the north and Akia ( $\mathrm{GM}=6 \mathrm{ng} / \mathrm{g} \mathrm{ww})$ in the middle part of the country [17]. However, $\mathrm{Pb}$ concentrations in the remaining districts in the present study were two to four times lower than those reported by the Greenlandic study.

As for $\mathrm{Cd}$, high $\mathrm{Pb}$ concentration in Fávrrosorda might be due to atmospheric deposition from the neighbouring district Ábborašša with its gold mining activity. 
Table 2. Concentrations of toxic elements $(\mathrm{ng} / \mathrm{g}$ wet $\mathrm{wt})$ in reindeer meat $(\mathrm{n}=90)$ from the ten different grazing districts.

\begin{tabular}{|c|c|c|c|c|c|c|c|c|c|c|c|}
\hline \multicolumn{12}{|c|}{ District } \\
\hline & & $\begin{array}{c}\text { ES- } \\
\text { Varanger }\end{array}$ & Pasvik & Varanger $\mathrm{P}$ & Spierttagáisá & Karasjok & Ábborašša & Fávrrosorda & Tromsdalen & Kanstadfjord & Essand \\
\hline \multirow[t]{5}{*}{ Cd } & GM & 0.9 & 1.5 & 1.4 & 0.9 & 0.9 & 2.2 & 4.3 & 0.9 & 5.1 & 3.6 \\
\hline & $\mathrm{AM} \pm \mathrm{SD}$ & $0.9 \pm 0.7$ & $1.9 \pm 2$ & $2.9 \pm 3.5$ & $0.9 \pm 0.5$ & $1.1 \pm 0.6$ & $2.9 \pm 2.5$ & $4.8 \pm 1.9$ & $0.9 \pm 0.3$ & $4.7 \pm 2.9$ & $4.4 \pm 2.8$ \\
\hline & Min-Max & $0.5-2.8$ & $0.8-7.6$ & $0.4-10.4$ & $0.4-2.1$ & $0.6-2.6$ & $0.9-8.2$ & $1.5-7.4$ & $<0.37-1.4$ & $1.6-10.8$ & $1.1-8.5$ \\
\hline & CV\% & 69 & 103 & 121 & 53 & 54 & 85 & 41 & 31 & 63 & 64 \\
\hline & $\mathrm{n}$ & 10 & 10 & 10 & 10 & 10 & 10 & 10 & 10 & 8 & 10 \\
\hline \multirow{5}{*}{$\mathbf{P b}$} & GM & 0.4 & 1.9 & 1.6 & 1.2 & 1 & 1.6 & 7.4 & 0.9 & 1.7 & 2.7 \\
\hline & $\mathrm{AM} \pm \mathrm{SD}$ & $0.7 \pm 0.5$ & $2.3 \pm 1.9$ & $2.1 \pm 1.4$ & $1.9 \pm 2.1$ & $2.2 \pm 2.5$ & $1.7 \pm 1.6$ & $8.6 \pm 4.9$ & $1.9 \pm 2.5$ & $2.5 \pm 1.9$ & $2.9 \pm 1.2$ \\
\hline & Min-Max & $<0.23-1.5$ & $1-7.8$ & $0.3-4.4$ & $<0.22-5.8$ & $<0.12-8.3$ & $0.18-4.6$ & $3.1-20$ & $<0.1-7.3$ & $0.27-5.6$ & $1.6-5.9$ \\
\hline & $\mathrm{CV} \%$ & 81 & 84 & 68 & 111 & 114 & 96 & 58 & 128 & 79 & 42 \\
\hline & $\mathrm{n}$ & 10 & 10 & 9 & 9 & 10 & 10 & 10 & 10 & 10 & 10 \\
\hline \multirow[t]{5}{*}{ As } & GM & 106 & 48 & 10 & 5.9 & 8.8 & 6.9 & 1.9 & 1.5 & 3.9 & 7.2 \\
\hline & $\mathrm{AM} \pm \mathrm{SD}$ & $107 \pm 17$ & $52 \pm 19$ & $11 \pm 3.3$ & $6.4 \pm 2.5$ & $8.9 \pm 1.5$ & $6.9 \pm 1.2$ & $2.2 \pm 1.1$ & $1.6 \pm 1.8$ & $4.1 \pm 0.7$ & $7.3 \pm 1.7$ \\
\hline & Min-Max & $84-135$ & $27-79$ & $7-16$ & $2.5-11$ & $6.3-11$ & $4.9-8.4$ & $0.9-3.9$ & $0.7-2.9$ & $2.9-4.9$ & $4.7-10$ \\
\hline & CV\% & 16 & 38 & 30 & 39 & 17 & 17 & 49 & 48 & 17 & 24 \\
\hline & $\mathrm{n}$ & 9 & 10 & 10 & 10 & 10 & 10 & 10 & 10 & 10 & 10 \\
\hline \multirow[t]{5}{*}{$\mathrm{Cu}$} & GM & 1,700 & 1,700 & 1,300 & 1,400 & 1,500 & 1,600 & 1,200 & 1,300 & 1,300 & 1,600 \\
\hline & $\mathrm{AM} \pm \mathrm{SD}$ & $1,700 \pm 292$ & $1,702 \pm 296$ & $1,326 \pm 194$ & $1,444 \pm 188$ & $1,549 \pm 276$ & $1,564 \pm 231$ & $1,208 \pm 274$ & $1,306 \pm 167$ & $1,287 \pm 275$ & $1,608 \pm 295$ \\
\hline & Min-Max & $1,300-2,100$ & $1,300-2,100$ & $1,100-1,600$ & $1,300-1,900$ & $1,200-2,100$ & $1,300-2,100$ & $800-1,700$ & $1,100-1,600$ & $800-1,600$ & $1,300-2,400$ \\
\hline & $\mathrm{CV} \%$ & 17 & 17 & 15 & 13 & 18 & 15 & 23 & 13 & 21 & 18 \\
\hline & $\mathrm{n}$ & 10 & 10 & 10 & 10 & 9 & 10 & 9 & 10 & 10 & 10 \\
\hline \multirow[t]{5}{*}{$\mathbf{N i}$} & GM & $<6.7$ & $<7.2$ & 0.8 & $<9.5$ & $<11$ & $<7.1$ & 1.2 & 1.3 & $<5.7$ & $<1.5$ \\
\hline & $\mathrm{AM} \pm \mathrm{SD}$ & $<6.7$ & $<7.2$ & $1.2 \pm 1.1$ & $<9.5$ & $<11$ & $<7.1$ & $2.7 \pm 2.5$ & $2.1 \pm 4.5$ & $<5.7$ & $<1.5$ \\
\hline & $\begin{array}{l}\text { Min.- } \\
\operatorname{Max}\end{array}$ & $<6.7-<14$ & $<7.2-<13$ & $<0.4-3.6$ & $<9.5-<39$ & $<11-11$ & $<7.1-<18$ & $<0.1-7.1$ & $<0.9-11$ & $<5.7-<20$ & $<1.5-5.8$ \\
\hline & $\mathrm{CV} \%$ & & & 93 & & & & 93 & 162 & & \\
\hline & $\mathrm{n}$ & 10 & 10 & 10 & 10 & 10 & 10 & 10 & 9 & 10 & 10 \\
\hline \multirow[t]{4}{*}{$\mathbf{V}$} & GM & $<0.01$ & $<0.02$ & $<2.7$ & 0.2 & $<0.26$ & $<0.24$ & $<1.9$ & $<0.9$ & $<0.09$ & $<0.02$ \\
\hline & $\mathrm{AM} \pm \mathrm{SD}$ & $<0.01$ & $<0.02$ & $<2.7$ & $0.3 \pm 0.6$ & $<0.26$ & $<0.24$ & $<1.9$ & $<0.9$ & $<0.09$ & $<0.02$ \\
\hline & $\begin{array}{c}\text { Min-Max } \\
\text { CV\% }\end{array}$ & $<0.01-0.2$ & $<0.02-0.3$ & $<2.7-<3.8$ & $\begin{array}{c}<0.09-3.8 \\
197\end{array}$ & $<0.02-8.3$ & $<0.24-0.39$ & $<1.9-<3.6$ & $<0.9-3.5$ & $<0.09-0.2$ & $<0.02-<0.2$ \\
\hline & $\mathrm{n}$ & 10 & 10 & 10 & 9 & 9 & 10 & 10 & 10 & 10 & 10 \\
\hline
\end{tabular}

Legend: $\mathrm{GM}=$ Geometric mean. AM = Arithmetic mean. SD = Standard deviation. Min.-Max. = Minimum - Maximum. $<\mathrm{X}=$ below limit of detection (LOD).

$\mathrm{CV}=$ Coefficient of variation. $\mathrm{n}=$ number of observations; Note: Numbers of observations less than 10 in some districts ( $\mathrm{n}=4$ districts) were due to exclusion of outliers. 
Table 3. Age stratified Cd concentration (ng/g ww) in reindeer meat from the grazing districts with mixed age groups.

\begin{tabular}{|c|c|c|}
\hline \multirow[b]{3}{*}{ Cd Concentration } & \multicolumn{2}{|c|}{ District } \\
\hline & \multicolumn{2}{|c|}{ Eastern Sør-Varanger } \\
\hline & Calves/Young $(\mathrm{n}=8)$ & Old $(n=2)$ \\
\hline & (10 months -1.5 years) & (>2 years) \\
\hline GM & 0.74 & 1.5 \\
\hline $\mathrm{AM}$ & 0.79 & 1.8 \\
\hline \multirow[t]{2}{*}{ Min-Max } & $0.5-1.5$ & $0.8-2.8$ \\
\hline & \multicolumn{2}{|c|}{ Varanger Peninsula } \\
\hline \multirow{2}{*}{ Cd Concentration } & Calves/Young $(\mathrm{n}=6)$ & Old $(n=4)$ \\
\hline & (10 months -1.5 years) & ( $>2$ years $)$ \\
\hline GM & 0.57 & 5.7 \\
\hline $\mathrm{AM}$ & 0.58 & 6.3 \\
\hline \multirow[t]{2}{*}{ Min-Max } & $0.4-0.7$ & $2.8-10$ \\
\hline & \multicolumn{2}{|c|}{ Kandstadfjord/Western Hinnøy } \\
\hline \multirow[t]{2}{*}{ Cd Concentration } & Calves/Young $(\mathrm{n}=6)$ & Old $(n=4)$ \\
\hline & (10 months -1.5 years) & (>2 years) \\
\hline GM & 3.4 & 5.2 \\
\hline AM & 4.3 & 5.2 \\
\hline Min-Max & $1.6-11$ & $4.1-6.2$ \\
\hline
\end{tabular}

\subsection{Arsenic (As)}

As was detected in all meat samples $(100 \%)$. The As was the element that showed most of the geographical variations (Table 2) among the studied elements. An east-west downward geographical gradient was observed for As, with the highest concentrations measured in the east (the three districts in the vicinity of the Russian border). However, a north-south trend (highest in the south) for As, Cd and $\mathrm{Pb}$ has previously been found in Norwegian surface soils, coniferous forest ecosystems and some herbivorous animals [2,26,37-39].

Due to the wind frequency towards the districts of Eastern Sør-Varanger and Pasvik/Sør-Varanger, the high As concentration in these districts could be explained in this study by the As being released from the smelter activity in the Russian town of Nikel, which was further reported to be higher during summer as compared to winter [20]. Furthermore, the wind from the east (E) brings waste from the town of Nikel towards the direction of Svanvik/Passvik, while the wind from the north $(\mathrm{N})$ and northeast (NE) brings waste from Zapoljarny during summer. The dominating wind in winter from the south (S) and south-west (SW) brings waste from Nikel to Jarfjord. However, the elevated As and Ni concentrations below the LOD in these two districts indicates additional As sources such as mining and geogenic sources in this area. The As concentrations in meat from Eastern Sør-Varanger $(\mathrm{GM}=106.1 \mathrm{ng} / \mathrm{g} \mathrm{ww})$ and Pasvik/Sør-Varanger $(\mathrm{GM}=47.9 \mathrm{ng} / \mathrm{g} \mathrm{ww})$ from this study were in agreement with those formerly revealed in liver samples from reindeer in the same area when compared with samples from other areas in the County [40]. By comparison, Bernhoft and colleagues 
reported median As concentration of $0.035 \mu \mathrm{g} / \mathrm{g}$ ww in reindeer liver collected from north western Russia [32].

The district of Ábborašša (gold mining activity) displayed As concentration (GM) three times higher than that found in the neighbouring district of Fávrrosorda, which could be explained by pollution from the mining work in the district, as As has been reported to be associated with gold mineralization $[41,42]$. In addition, the district of Spierttagáisá (military activity) revealed a lower As concentration $(\mathrm{GM}=5.9 \mathrm{ng} / \mathrm{g} \mathrm{ww})$ than that $(\mathrm{GM}=8.8 \mathrm{ng} / \mathrm{g} \mathrm{ww})$ found in the neighbouring district of Karasjok West, although the difference was not statistically significant. The As concentration in samples from Essand/Røros was similar to those detected in Ábborašša (gold mining activity) and Spierttagáisá (military activity). This could be due to the long-range atmospheric pollution from Europe, as a previous study has demonstrated that southern Norwegian areas are more prone to atmospheric pollution from Europe than the northern areas [43]. Contribution from soil due to geogenic sources could also lead to elevated As level in the surrounding environment. In accordance with previous study, the reindeer's age and sex had no effect on the arsenic concentration [32].

\subsection{Copper (Cu)}

$\mathrm{Cu}$ was detected in all meat samples (100\%) and had the highest concentration among all the studied elements $(\mathrm{GM}=1,439 \mathrm{ng} / \mathrm{g} w \mathrm{w})$. Cu concentrations did not vary much among the districts (Table 2). Study on Finnish reindeer had also reported little differences in concentrations of $\mathrm{Cu}$ among different Lapland areas [15].

$\mathrm{Cu}$ concentrations detected in this study were in agreement with those reported from Finnish Lapland and Russian Karelia, and were half of those reported from Greenlandic reindeer muscle $[15,17,33]$. The results for the effect of age and sex on $\mathrm{Cu}$ concentrations from this study stand in contradiction to those reported by Bernhoft and colleagues, in which hepatic $\mathrm{Cu}$ concentration was higher in reindeer calves than in adult females, and higher in adult males than in adult females [32].

Districts that displayed relatively high $\mathrm{Cu}$ concentrations could be due to contamination from local point sources (gold mining in Ábborašša) and atmospheric transportation in Pasvik and Eastern SørVaranger (Russian towns of Nikel with its nickel smeltery and Zapoljarny with its briquette industry) [16].

\subsection{Nickel (Ni)}

Ni was detected in samples from five of the 10 districts (Fávrrosorda, Tromsdalen, Varanger Peninsula, Karasjok West and Essand/Røros) and in $20 \%$ of the total meat samples $(n=100)$. The Ni detection percentage within these five districts varied as follows: 80\% (Fávrrosorda), 60\% (Tromsdalen), 40\% (Varanger Peninsula) and 10\% in the districts of Karasjok West and Essand/Røros.

The districts of Varanger Peninsula, Fávrrosorda and Tromsdalen had geometric/arithmetic mean Ni concentrations above the LOD (Table 2), in which the Ni concentrations were comparable.

Previous studies on human Ni exposure along the Norwegian-Russian border have shown that urinary Ni concentrations in this area were no higher than the ones exhibited in other populations [44]. No data were available on $\mathrm{Ni}$ and $\mathrm{V}$ from reindeer muscle other than that of the Ni concentration from the Karelian Russian reindeer, which was reported to be below the LOD [33]. Nonetheless, the Ni concentrations formerly reported in liver and kidney samples from reindeer originating from the 
Norwegian-Russian border (Sør-Varanger, north eastern Norway and Rybatsjy Ostrov, north western Russia) had exhibited geographical variations and were much higher in levels than those documented in this study due to tissue differences [16,32].

\subsection{Vanadium $(V)$}

$\mathrm{V}$ was detected in $21 \%$ of the total meat samples $(\mathrm{n}=100)$ and in seven of the 10 districts (Kanstadfjord, Tromsdalen, Pasvik, Spierttagáisá, Karasjok West, Eastern Sør-Varanger and Ábborašša). The detection percentages within these seven districts varied as follows: 50\% (Spierttagáisá), 40\% (Kanstadfjord), 30\% (Eastern Sør-Varanger, Pasvik and Ábborašša) and 10\% in Tromsdalen and Karasjok West. The district Spierttagáisá was the only one that had geometric/arithmetic mean $\mathrm{V}$ concentration $(0.2 / 0.3 \mathrm{ng} / \mathrm{g} \mathrm{ww})$ above the LOD.

$\mathrm{V}$ has been described as a useful environmental pollution marker for the potential release of toxic elements from fossil fuels and oil refinery processes [45]. Results on V from Canadian (Yukon) caribou kidney reported an average concentration of $0.42 \mu \mathrm{g} / \mathrm{g}$ dry weight, $79.9 \%$ moisture [3].

\subsection{Risk Assessment of Toxic Elements from Reindeer Meat Consumption}

Reindeer meat is consumed as fresh, smoked or dried products in Norway, with the highest consumption among the indigenous Sami people, particularly reindeer herders and their families, compared to ethnic Norwegians [46]. The average consumption is generally low compared to other meat types and constitute approximately $23 \mathrm{~g}$ and $70 \mathrm{~g} /$ week for low and high consumers in areas with both Sami and ethnic Norwegians [47,48]. The estimated human toxic elements intake from reindeer meat based on the high consumption ( $70 \mathrm{~g}$ meat/week) were 0.01 and $0.01 \mu \mathrm{g} / \mathrm{kg}$ human body weight for $\mathrm{Cd}$ and As, respectively. These estimations (monthly for $\mathrm{Cd}$ and weekly for As) were much lower than permissible tolerable monthly intake (PTMI) for Cd (25 $\mu \mathrm{g} / \mathrm{kg}$ human body weight) and weekly intake (PTWI) of $15 \mu \mathrm{g} / \mathrm{kg}$ human body weight for As [49,50]. The FAO/WHO-JECFA has recently withdrawn the PTWI limit of $25 \mu \mathrm{g} / \mathrm{kg}$ human body weight for $\mathrm{Pb}$ due to its association with a decrease of at least three intelligence quotient (IQ) points in children and an increase in systolic blood pressure of approximately $3 \mathrm{mmHg}$ in adults [49]. No new PTWI limit was established for Pb. Nevertheless, weekly human $\mathrm{Pb}$ exposure from reindeer meat of $0.002 \mu \mathrm{g} / \mathrm{kg}$ human body weight was 12,500 times lower than the previous PTWI limit. The estimated daily $\mathrm{Cu}$ intake from reindeer meat in this study was about $0.0003 \mathrm{mg} / \mathrm{kg}$ body weight which was well below the acceptable daily intake (ADI) of $0.5 \mathrm{mg} / \mathrm{kg}$ body weight [51]. There are no established PTWI/PTMI limits for Ni and V. Nevertheless, concentrations of $\mathrm{Ni}$ and $\mathrm{V}$ detected in the present study were considerably lower than tolerable upper intake levels of $1 \mathrm{mg}$ and $1.8 \mathrm{mg}$ per day that have been reported elsewhere for $\mathrm{Ni}$ and $\mathrm{V}$, respectively [52].

Estimation of human exposure to toxic elements through reindeer meat was previously done based on dietary data from a questionnaire on the Population-based Health and Living Conditions in areas with Sami and Norwegian populations-The SAMINOR Study and the equation described in one of our previous studies [47,48]. The dietary data from the questionnaire and calculations based on the equation mentioned above have revealed considerably low human exposure to toxic elements through meat and other edible tissues from reindeer. 
The presence of individual animals with elevated toxic element concentrations (outliers) was investigated further by relating these concentrations to concepts such as maximum levels (ML), acceptable daily intakes (ADI), professional tolerable intakes (PTI) and healthy animals' parameters $[12,49,50,53]$. For instance, the elevated concentrations of outliers in cases of cadmium (13 and $15 \mathrm{ng} / \mathrm{g} \mathrm{ww}$ ) and lead (23 and $28 \mathrm{ng} / \mathrm{g} \mathrm{ww}$ ) have been estimated to constitute $20 \%$ and $40 \%$ of the maximum levels (ML) set for $\mathrm{Cd}$, and $20 \%$ and $30 \%$ of the ML set for $\mathrm{Pb}$ [53]. Consequently, the elevated concentrations measured in this study should not be an issue of concern to consumers.

\section{Conclusions}

Arsenic and cadmium were the elements that exhibited most of the geographical differences. No clear geographical trend was observed except for the east-west gradient for As, with the highest concentrations measured in the east (near the Russian border). The presence of older animals ( $>2$ years) displayed an age effect as animals more than 2 years old demonstrated higher cadmium concentration than ones $<2$ years old, whereas sex had no significant effect on toxic element concentrations. The concentrations of the toxic elements detected in this study were low and considerably below the maximum levels (ML) and permissible tolerable weekly/monthly intake (PTWI/PTMI) limits available for hazardous toxic elements. This suggests that the use of reindeer meat as human food is safe in relation to toxic elements, even along the Norwegian-Russian border where previous studies have revealed elevated concentrations in liver and kidneys from reindeer [16]. Based on the result from the present study, we have no reason to warn people against eating reindeer meat. Further investigations regarding arsenic findings are needed.

\section{Conflict of Interest}

The authors declare no conflict of interest.

\section{Acknowledgements}

The authors wish to thank Thor Aage Pedersen, Mikkel Triumph, Per Mathis Oskal, the Hansen family and Arnstein Stensaas, the owners of the reindeer slaughterhouses who provided free meat samples. Thanks are also due to the slaughterhouse operators for their cooperation during the sample collection. We are grateful to the Meat Inspection Unit of the Norwegian Food Safety Authority District Office of Mid-Finnmark in Karasjok for giving us access to their laboratory during the sample preparation. We also want to thank the other meat inspection units in the districts where the samples were collected for their kind help. This study was funded by the Reindeer Husbandry Development Fund (RUF) in Alta and the Centre for Sami Health Research in Karasjok, Norway. 


\section{References}

1. Froslie, A.; Haugen, A.; Holt, G.; Norheim, G. Levels of cadmium in liver and kidneys from Norwegian cervides. Bull. Environ. Contam. Toxicol. 1986, 37, 453-460.

2. Froslie, A.; Norheim, G.; Rambaek, J.P.; Steinnes, E. Levels of trace elements in liver from Norwegian moose, reindeer and red deer in relation to atmospheric deposition. Acta Vet. Scand. 1984, 25, 333-345.

3. Gamberg, M. Contaminants in Yukon Moose and Caribou-2003; Gamberg Consulting: Whitehorse, Yukon, Canada, 2004; p. 16.

4. Frøslie, A.; Holt, G.; Høie, R. Levels of copper, selenium and zinc in liver of Norwegian moose (Alces alces), reindeer (Rangifer tarandus), roedeer (Capreolus capreolus) and hare (Lepus timidus). Norsk Landbruksforskning 1987, 1, 243-249.

5. Reindriftsforvaltningen. Ressursregnskap for Reindriftsnoeringen (Resource Accounts for Reindeer Husbandary Management); Reindriftsforvaltningen (Reindeer Husbandary Management): Alta, Norway, 2010; p. 143.

6. Reindriftsforvaltningen, Ressursregnskap for Reindriftsnoeringen (Resource Accounts for Reindeer Husbandary Management); Reindriftsforvaltningen (Reindeer Husbandary Management): Alta, Norway, 2003; p. 141.

7. Underwood, E.J. Trace Elements in Human and Animal Nutrition, 4th ed.; Academic Press: New York, NY, USA, 1977; p. 545.

8. Järup, L. Hazards of heavy metal contamination. Brit. Med. Bull. 2003, 68, 167-182.

9. Buchet, J.P.; Lauwerys, R.; Roels, H.; Bernard, A.; Bruaux, P.; Claeys, F.; Ducoffre, G.; de Plaen, P.; Staessen, J.; Amery, A.; et al. Renal effects of cadmium body burden of the general population. Lancet 1990, 336, 699-702.

10. Nriagu, J.O. A silent epidemic of environmental metal poisoning? Environ. Pollut. 1988, 50, $139-161$.

11. Oehme, F.W. Toxicity of Heavy Metals in the Environment; Marcel Dekker: New York, NY, USA, 1978; Volume 1, p. 515.

12. Kahn, C. M. The Merck Veterinary Manual, 10th ed.; Merck \& Co., Inc.: Whitehouse Station, NJ, USA, 2010; pp. 28-33.

13. Robillard, S.; Beauchamp, G.; Paillard, G.; Belanger, D. Levels of cadmium, lead, mercury and (137) caesium in caribou (Rangifer tarandus) tissues from northern Quebec. Arctic 2002, 55, 1-9.

14. Medvedev, N. Concentrations of cadmium, lead and sulphur in tissues of wild, forest reindeer from north-west Russia. Environ. Pollut. 1995, 90, 1-5.

15. Rintala, R.; Venalainen, E.R.; Hirvi, T. Heavy-metals in muscle, liver, and kidney from Finnish reindeer in 1990-91 and 1991-92. Bull. Environ. Contam. Toxicol. 1995, 54, 158-165.

16. Sivertsen, T.; Daae, H.L.; Godal, A.; Sand, G. Ruminant uptake of nickel and other elements from industrial air pollution in the Norwegian-Russian border area. Environ. Pollut. 1995, 90, 75-81.

17. Aastrup, P.; Riget, F.; Dietz, R.; Asmund, G. Lead, zinc, cadmium, mercury, selenium and copper in Greenland caribou and reindeer (Rangifer tarandus). Sci. Total Environ. 2000, 245, 149-159. 
18. Farmer, A.A.; Farmer, A.M. Concentrations of cadmium, lead and zinc in livestock feed and organs around a metal production centre in eastern Kazakhstan. Sci. Total Environ. 2000, 257, $53-60$.

19. Eriksson, O.; Frank, A.; Nordkvist, M.; Petersson, L.R. Heavy metals in reindeer and their forage plants. Rangifer 1990, 3, 315-331.

20. Berglen, T.F.; Andersen, E.; Arnesen, K.; Kalvenes, Ø.; Ofstad, T.; Rode, A.; Tønnesen, D.; Uggerud, H.T.; Vadset, M. Air and Precipitation Quality in the Norwegian-Russian Boarder. April 2009-March 2010; Norwegian Institute for Air Research (NILU): Oslo, Norway, 2010; p. 99.

21. AMAP. AMAP Assessment 2002: Heavy Metals in the Arctic; AMAP: Oslo, Norway, 2005; p. 265.

22. Howell, J.M. Toxicities and Excessive Intakes of Minerals. In Detection and Treatment of Mineral Nutrition Problems in Grazing Sheep; Masters, D.G., White, C.I., Eds.; Australian Centre for International Agricultural Research (ACIAR): Canberra, Australia, 1996; pp. 95-117.

23. Wilson, M.J.; Bell, N. Acid deposition and heavy metal mobilization. Appl. Geochem. 1996, 11, $133-137$.

24. Blake, L.; Goulding, K.W.T. Effects of atmospheric deposition, soil pH and acidification on heavy metal contents in soils and vegetation of semi-natural ecosystems at Rothamsted Experimental Station, UK. Plant Soil 2002, 240, 235-251.

25. Steinnes, E.; Allen, R.O.; Petersen, H.M.; Rambæk, J.P.; Varskog, P. Evidence of large scale heavy-metal contamination of natural surface soils in Norway from long-range atmospheric transport. Sci. Total Environ. 1997, 205, 255-266.

26. Overrein, L.N.; Seip, H.M.; Tollan, A. Acid Precipitation-Effects on Forest and Fish; Final Report of the SNSF-Project 1972-1980;SNSF Project: Oslo, Norway, 1980; p. 175.

27. Garmo, T.H. Chemical composition and in vitro dry matter digestibility of lichens. Rangifer 1986, $6,8-13$.

28. Larsen, D.W. The absorption and release of water by lichens. Bibli Lichenologica 1987, 25, 351-360.

29. Nieboer, E.; Richardson, D.H.S.; Tomassini, F.D. Mineral uptake and release by lichens: An overview. Bryologist 1978, 81, 226-246.

30. Sivertsen, B.; Bekkestad, T. Air Pollution Impact in the Border Areas of Norway and Russia. Trends and Episodes. In The Second Syposium on Effects of Air Pollutants on Terrestrial Ecosystems in the Border Area between Norway and Russia, October 1994, Svanvik, Norway, Venn, E.L.a.K., Ed.; Directorate for Nature Management: Svanvik, Norway, 1995; p. 140.

31. Gilbert, R.O. Statistcal Methods for Environmental Pollution Monitoring; John Wiley \& Sons Inc.: New York, NY, USA, 1987; p. 319.

32. Bernhoft, A.; Waaler, T.; Mathiesen, S.D.; Flåøyen, A. Trace elements in reindeer from Rybatsjij Ostrov, north western Russia. Rangifer 2002, 22, 67-73.

33. Medvedev, N. Levels of heavy metals in Karelian wildlife, 1989-91. Environ. Monit. Assess. 1999, 56, 177-193.

34. Krug, E.C.; Frink, C.R. Acid rain on acid soil: A new perspective. Science 1983, 22, 520-525.

35. Abrahamsen, G.; Stuanes, A.O.; Tveite, B. Long-Term Experiments with Acid Rain in Norwegian Forest Ecosystems; Springer-Verlag: New York, NY, USA, 1993; p. 342. 
36. Abrahamsen, G.; Horntvedt, R.; Tveite, B. Impacts of acid precipitation on coniferous forest ecosystems. Water Air Soil Pollut. 1977, 8, 57-73.

37. Hvatum, O.Ø.; Bølviken, B.; Steinnes, E. Heavy metals in Norwegian ombrotrophic bogs. Ecol. Bull. 1983, 35, 351-356.

38. Steinnes, E. Impact of Long-Range Atmospherictransport of Heavy Metals to the Terrestrial Environment in Norway. In Lead, Mercury, Cadmium and Arsenic in the Environment; Hutchinson, T.C., Meema, K.M., Eds.; John Wiley \& Sons Ltd: New York, NY, USA, 1987; pp. 107-117.

39. Froslie, A.; Norheim, G.; Rambaek, J.P.; Steinnes, E. Heavy metals in lamb liver: Contribution from atmospheric fallout. Bull. Environ. Contam. Toxicol. 1985, 34, 175-82.

40. Sivertsen, T.; Daae, H.L.; Godal, A.; Sand, G. Ruminant uptake of nickel and other elements from industrial air-pollution in the Norwegian-Russian border area. Environ. Pollut. 1995, 90, 75-81.

41. Asadi, H.H.; Voncken, J.H.L.; Hale, M. Invisible gold at Zarshuran, Iran. Econ. Geol. 1999, 94, 1367-1374.

42. Eisler, R. Arsenic hazards to human, plants and animals from gold mining. Rev. Environ. Contam. Toxicol. 2004, 180, 133-165.

43. Steinnes, E.; Solberg, W.; Petersen, H.M.; Wren, C.D. Heavy metal pollution by long range atmospheric transport in natural soils of southern Norway. Water Air Soil Pollut. 1989, 45, 207-218.

44. Smith-Sivertsen, T.; Lund, E.; Thomassen, Y.; Norseth, T. Human nickel exposure in an area polluted by nickel refining: The Sør-Varanger study. Arch. Environ. Health 1997, 52, 464-471.

45. Soldi, T.; Riolo, C.; Alberti, G.; Gallorini, M.; Peloso, G.F. Environmental vanadium distribution from an industrial settlement. Sci. Total. Environ. 1996, 181, 45-50.

46. Nilsen, H.; Utsi, E.; Bønaa, K.H. Dietary and nutrient intake of a Sami population living in traditional reindeer herding areas in north Norway: Comparisons with a group of Norwegians. Int. J. Circumpolar Health 1999, 58, 120-133.

47. Hassan, A.A.; Rylander, C.; Brustad, M.; Sandanger, T.M. Level of selected toxic elements in meat, liver, tallow and bone marrow from young semi-domesticated reindeer (Rangifer tarandus tarandus L.) form Northern Norway. Int. J. Circumpolar Health 2012, 71, doi:10.3402/ijch.v71i0.18187.

48. Brustad, M.; Parr, C.L.; Melhus, M.; Lund, E. Dietary patterns in the population living in the Sámi core areas of Norway-The SAMINOR study. Int. J. Circumpolar Health 2008, 67, 82-96.

49. WHO. Summary and Conclusions. In Proceedings of the Joint FAO/WHO Expert Committee on Food Additives (JECFA/73/SC), 73rd Meeting; WHO: Geneva, Switzerland, 2010; p. 22.

50. WHO. Summary and Conclusions (JECFA/72/SC). In Proceedings of the Joint FAO/WHO Expert Committee on Food Additives, 72nd Meeting, Rome, Italy, 16-25 February 2010. p. 16.

51. WHO. Trace Elements in Human Nutrition. In Proceedings of the FAO/WHO Expert Committee on Food Additives (JECFA) Meeting, Geneva, Switzeralnd, 24 June-2 July 1970; FAO/WHO JECFA: Geneva, Switzerland, 1971.

52. Insel, P.M.; Turner, R.E.; Ross, D. Nutrition, 2nd ed.; Jones and Bartletts Publishers Inc.: Sudbury, MA, USA, 2004; Volume 1; p. 740.

53. EC. Commission regulation (EC) No. 1881/2006, setting maximum levels for certain contaminants in foodstuffs. Off. J. Eur. Union 2006, L364/5-L364/24. 


\section{Supplemental Material}

Table S1. Geographical differences in concentrations of the studied toxic elements among the ten grazing districts.

\begin{tabular}{|c|c|c|c|c|c|}
\hline Toxic element & $\mathbf{n}$ & & District $\mathrm{X}$ & t Y (P-value) & \\
\hline \multirow[t]{5}{*}{$\mathrm{Cd}$} & 98 & & & & \\
\hline & & Kanstadfjord: Tromsdalen $* *$ & Kanstadfjord: Spierttagáisá ** & Kanstadfjord: Karasjok $* *$ & Kanstadfjord: E. S-Varanger ** \\
\hline & & Tromsdalen: Fávrrosorda $* *$ & Tromsdalen: Essand $* *$ & Fávrrosorda: Varanger $\mathrm{P} * *$ & Fávrrosorda: Pasvik * \\
\hline & & Fávrrosorda: Spierttagáisá ** & Fávrrosorda: Karasjok ** & Fávrrosorda: E. S-Varanger ** & Spierttagáisá: Essand $* *$ \\
\hline & & Karasjok: Essand** & E. S-Varanger: Essand ** & & \\
\hline \multirow[t]{3}{*}{$\mathrm{Pb}$} & 98 & & & & \\
\hline & & Tromsdalen: Fávrrosorda $* *$ & Fávrrosorda: Spierttagáisá * & Fávrrosorda: Karasjok $* *$ & Fávrrosorda:E. S-Varanger ** \\
\hline & & Fávrrosorda: Ábborašša ** & Pasvik: E. S-Varanger * & E. S-Varanger: Essand $* *$ & \\
\hline \multirow[t]{9}{*}{ As } & 99 & & & & \\
\hline & & Kanstadfjord: Tromsdalen $* *$ & Kanstadfjord: Fávrrosorda ** & Kanstadfjord: Varanger $\mathbf{P} * *$ & Kanstadfjord: Pasvik $* *$ \\
\hline & & Kanstadfjord: Karasjok $* *$ & Kanstadfjord:E. S-Varanger $* *$ & Kanstadfjord: Essand $*$ & Kanstadfjord: Ábborašša * \\
\hline & & Tromsdalen: Varanger $\mathbf{P} * *$ & Tromsdalen: Pasvik $* *$ & Tromsdalen: Spierttagáisá $* *$ & Tromsdalen: Karasjok $* *$ \\
\hline & & Tromsdalen: E. S-Varanger $* *$ & Tromsdalen: Essand $* *$ & Tromsdalen: Ábborašša ** & Fávrrosorda: Varanger $\mathbf{P} * *$ \\
\hline & & Fávrrosorda: Pasvik ** & Fávrrosorda: Spierttagáisá ** & Fávrrosorda: Karasjok ** & Fávrrosorda:E. S-Varanger ** \\
\hline & & Varanger P:E. S-Varanger ** & Pasvik: Spierttagáisá ** & Pasvik: Karasjok ** & Pasvik: E. S-Varanger $* *$ \\
\hline & & Pasvik: Essand $* *$ & Pasvik: Ábborašša ** & Spierttagáisá: E. S-Varanger ** & Karasjok: E. S-Varanger $* *$ \\
\hline & & E. S-Varanger: Essand** & E. S-Varanger: Ábborašša** & & \\
\hline \multirow[t]{3}{*}{$\mathrm{Cu}$} & 98 & & & & \\
\hline & & Kanstadfjord: Pasvik * & Kanstadfjord: E. S-Varanger * & Fávrrosorda: Pasvik ** & Fávrrosorda: E. S-Varanger $* *$ \\
\hline & & Fávrrosorda: Essand * & Fávrrosorda: Ábborašša * & & \\
\hline
\end{tabular}

(C) 2012 by the authors; licensee MDPI, Basel, Switzerland. This article is an open access article distributed under the terms and conditions of the Creative Commons Attribution license (http://creativecommons.org/licenses/by/3.0/). 